\title{
ЕКОЛОГІЧНА БЕЗПЕКА
}

УДК 629.5.068.4

doi.org/10.33298/2226-8553/2020.1.29.10

Пизинцали Л.В., Александровская Н.И., Россомаха Е.И., Никифоров Ю.А., Шахов В.И., Рабочая T.B.

\section{ПРИНЦИПЫ ФОРМИРОВАНИЯ СИСТЕМЫ ЭКОЛОГИЧЕСКОГО МЕНЕДЖМЕНТА ПРЕДПРИЯТИЯ ПО УТИЛИЗАЦИИ МОРСКИХ СУДОВ В УКРАИНЕ}

Утилизация отслужсивших свой срок судов и кораблей различных типов и назначения актуальная и, одновременно, весьма сложная и серьезная проблема не только в технологическом, экономическом $и$ правовом плане, но, $и$ является серьезной экологической проблемой.

Авторы подчеркивают, что в принятой стратегии для развязывания системных проблем не предусмотрены новые пути и эффективные методы восстановления и развития судоремонтных заводов Украины, и вообще не упоминается о проблемах большого количества брошенных и затопленных судов, пристаней, доков, причалов в затоках, в устьях рек и даже в портах.

При эффективной системе господдержки судостроение даст толчок для других отраслей (машиностроение, металлургия и др.).

В условиях функиионирования системы экологического управления производственная деятельность на предприятии по утилизации морских судов, по мнению авторов, может быть представлена в виде различных видов экологической деятельности (разработка, обоснование, анализ, оценки и т.д.), взаимосвязанных между собой).

По мнению авторов, один из путей реанимирование судостроительных и судоремонтных заводов, является перепрофилирование их полностью или частично в утилизачионное предприятие. Вложения будут относительно минимальные, так как, будет сохранена техническая база, жив и работает научно-исследовательский потенциал, способный обеспечить заводы современными проектами и разработками, а также, обязательно нужно отметить выгодное географическое положение, и прекрасные климатические условия.

В статье показано значение, роль и влияние системь экологического менеджмента на создание, и управление утилизащионного предприятия. Проведено обобщение стандартов ISO 14000.

Ключевые слова: утилизационное предприятие, экологический менеджмент, система экологического менеджмента, окружающая среда, стандарты ISO 14000.

Постановка проблемы. Среди современных глобальных мировых проблем человечества экологические проблемы занимают едва ли не самое главное место. Охране окружающей среды (OC) и рациональному использованию природных ресурсов в настоящее время уделяют особое внимание правительственные структуры и международная общественность. На повестку дня выносится вопрос экологической безопасности государства. 
Число морских судов в мире постоянно растет, соответственно возрастет и количество отслуживших свой срок судов.

Согласно Резолюиии A. 962(23), утилизация является наилучшим вариантом удаления всех отслуживших срок судов [1].

По итогам 2019 года, согласно данным неправительственной организации Ship breaking Platform, в мире было продано 674 судна на утилизацию: 479 судов - танкеров, сухогрузов, морских платформ, пассажирских судов, утилизированы на трех так называемых «токсичных» судоразделочных «пляжах» - в Бангладеш, Индии и Пакистане. Это 90\% от валовой вместимости всех списанных на слом судов. В Бангладеш утилизировано самое большое количество судов - 276 ед. общей валовой вместимостью 7,8 млн тонн, в Индии 200 судов (валовой вместимостью 3,6 млн тонн), в Турции - 107 судов (валовой вместимостью 1,2 млн тонн), в Китае - 29 судов (валовой вместимостью 304 тыс тонн), в странах Эвросоюза - 29 судов (валовой вместимостью 60 тыс тонн), в других странах - 24 судна (валовой вместимостью 180 тыс тонн), в России - 16 судов.

За 2019 год больше всего судов на утилизацию на «токсичные верфи» отправила тайваньская Evergreen, в Бангладеш. Так же в списке Maersk Costamare, CMACGM, Diamond Offshore, ENSCO, MOL. MSC и NYR [2].

Быстрое увеличение объемов образования судов-отходов - одна из актуальных проблем загрязнения OC не только в Украине, но и в мире. Последствия динамики образования судовотходов и увеличения доли прямого их затопления или бросания у причалов, у берегов рек, в затоках и т.д. приводят к появлению, в первую очередь, факторов экологической опасности.

Утилизация отслуживших свой срок судов и кораблей различных типов и назначения актуальная и, одновременно, весьма сложная и серьезная проблема не только в технологическом, экономическом и правовом плане, но, и является серьезной экологической проблемой.

По мнению авторов, именно экологические проблемы являются препятствием на пути создания и развития утилизационных предприятий (УП) морских судов в Украине.

В условиях современной чрезвычайно сложной экологической ситуации в Украине особое значение приобретает использование и исследование экологического менеджмента (ЭМ) на УП морских судов.

В Украине, наблюдается тенденция, когда предприятия неохотно внедряют системы экологического менеджмента (СЭМ) и экологическую политику. По нашему мнению, использование СЭМ при создании и управлении УП, позволит не только улучшить состояние ОС, повысить эффективность работы по охране ОС, контролировать требования законов Украины по охране ОС, снизить риски возникновения аварийных ситуаций, но и сэкономить ресурсы, и снизить расходы. Наличие сертификата ISO 14001 способствует росту интереса к УП, как потребителей, так и инвесторов.

Практика предприятий мира, которые внедряют СЭМ удостоверяет, что расходы компенсируются за 2 - 4 года и дают возможность предприятиям экономить значительные ресурсы [3].

С учетом выше сказанного, авторы считают, что обеспечение ЭМ на УП приведет к снижению загрязнения ОС (даже в условия нехватки государственных средств) и будет выгодно как для государства, так и для УП.

Анализ научных исследований и публикаций. Среди основных направлений решения проблем, возникающих при управлении утилизацией морских судов, могут быть выделены:

- проблемы развития утилизации морского транспорта [4-8]. В частности, в работе [4] показана динамика роста флота за 2000 - 2017 гг., распределение заказов по странам; в работе [5] рассмотрены вопросы, связанные с проблемой утилизации морского транспорта, предпосылки создания УП; в работе [6] проведен анализ состояния законодательного, организационного и технологического уровней утилизации судов в Украине, определены перспективы развития предприятия на базе имеющихся судостроительных и судоремонтных 
заводов юга Украины; автором [7] разработана современная методика проведения перспективного анализа финансово-хозяйственной деятельности предприятия-утилизатора; в работе [8] указано на важность проблемы, связанной с управлением отходами производства посредством создания УП.

- вопросы ЭМ в работах [9 - 11]. В частности, в работе [9] рассмотрена идеология корпоративного ЭМ и условия сертификации предприятия на соответствие требованиям стандарта ИСО 14001. Показано влияние на ОС; в работе [10] показано, что обновление стандартов ISO 9001 не меняет сути предыдущей версии, а связано, прежде всего, с необходимостью повышения его совместимости с другими стандартами, в частности со стандартом ISO 14001, применяемым к СЭМ; в работе [11] представлен анализ новых требований и руководящих указаний международного стандарта ISO 14001 версии 2015 года к СЭМ.

- вопросы организационно-методологического обеспечения ЭМ как фактора устойчивого развития [12 - 17]. В частности, в работе [12] рассмотрена идеология корпоративного ЭМ и условия сертификации предприятия на соответствие требованиям стандарта ИСО 14001. Показано влияние открытых горнодобывающих работ на ОС; в работе [13] показана необходимость повышения совместимости стандарта ISO 9001:20082 с другими стандартами, в частности со стандартом ISO 14001:2004, применяемым к системам ЭМ; в работе [14] представлен анализ новых требований и руководящих указаний международного стандарта ISO 14001 версии 2015 года к СЭМ. Как показано в статье, особые сложности адаптации к новым базовым требованиям связаны с необходимостью внедрения сертифицированными организациями таких инструментов ЭМ как оценка и управление жизненным циклом продукции/услуг, внедрение индикаторов экологической результативности, расширенного диалога с заинтересованными сторонами, анализа контекста организации, лидерства руководства, управления документированной информацией, процессного и рискориентированного подходов в менеджменте; в работе [15] рассматриваются проблемы учета экологического фактора при принятии управленческих решений и переходе на экологоэкономическую систему управления. Показаны позитивные стороны внедрения СЭМ на предприятиях; в работе [16] рассматриваются сущность, содержание и функции ЭМ; В работе [17] рассматривается важность ЭМ на предприятии, преимущества внедрения СЭМ. Определены достоинства и недостатки ЭМ на предприятиях энергетической отрасли, предложены рекомендации по совершенствованию экологического управления на предприятиях.

По результатам анализа есть основания считать:

- проблема утилизации судов в Украине не была решена в XX веке и более обостренной перешла в XXI век;

- несмотря на многочисленные исследования, отсутствует информация о принципах формирования системы ЭМ предприятия по утилизации морских судов вообще, и в частности в Украине;

- отсутствует информация об использовании стандартов GPM Global P5 в интегрированной системе менеджмента УП, поэтому есть необходимость проведения, в дальнейшем, исследований и в этом направлении;

- научные исследования экологической политики должны углубляться и сопровождаться поисками новых подходов управления, в частности на УП морских судов.

Цель статьи - обозначить основные принципы формирования СЭМ предприятия по утилизации морских судов.

Изложение основного материала.

Кабинет Министров Украины своим распоряжением от 30 мая 2018 р. №430 одобрил Национальную транспортную стратегия Украины на период до 2030 года.

Авторы полностью согласны с работой [18], что принятая стратегия не позволит решить основные проблемы и на судоремонтных заводах - технологическую отсталость и 
неэффективность работы, высокую степень физического и морального износа основных фондов, очень незначительное или вообще отсутствие финансирования для возрождения и модернизации инфраструктуры, потерю транзитных грузопотоков, которые все чаще направляются в обход территории Украины, развитие системы безопасности в украинских портах и т.п.

Авторы подчеркивают, что в принятой стратегии для развязывания системных проблем не предусмотрены новые пути и эффективные методы восстановления и развития судоремонтных заводов Украины, и вообще не упоминается о проблемах большого количества брошенных и затопленных судов, пристаней, доков, причалов в затоках, в устьях рек и даже в портах.

Хочется подчеркнуть, что непрофессиональные реформы, которые продолжаются в морской отрасли последние десятилетие, фактически разрушили не только судоремонт, но и, например систему безопасности в украинских портах. И яркий, плачевный пример тому происшествие с танкером Delfi у берегов Одессы (Это вывод по результатам прессконференции 29 ноября в Укринформе "Авария танкера Delfi в Одессе. Кто виноват, кроме шторма?").

При эффективной системе господдержки судостроение даст толчок для других отраслей (машиностроение, металлургия и др.). По оценкам центра транспортных стратегий - ЦТС и «Укрречфлота», один доллар инвестиций в судостроение дает несколько долларов потребления в смежных областях. Если взять за основу, например речные перевозки, то для удовлетворения спроса объемом 32 млн т, нужно построить более 250 ед. речного флота. Это потребует более $\$ 1,6$ млрд инвестиций. За 10 лет эти вложения сгенерируют создание более 8,3 тыс. рабочих мест, рост потребления в смежных отраслях на уровне \$2,6 млрд, около \$732 млн бюджетных отчислений и более \$1 млрд зарплат [19].

По нашему мнению, один из путей реанимирования судостроительных и судоремонтных заводов, является перепрофилирование их полностью или частично в УП. Вложения будут относительно минимальные, так как, во-первых, сохранена техническая база; во-вторых, жив и работает научно-исследовательский потенциал, способный обеспечить заводы современными проектами и разработками, как по строительству флота, так и реконструкции и модернизации заводов. Например, в городах Одесса и Николаев находятся более 20 научно - исследовательских предприятий, высших и средне - специальных учебных заведений, сеть колледжей и морских школ. В-третьих, нельзя не отметить и выгодное географическое положение, и прекрасные климатические условия: короткий зимний период со стабильными плюсовыми температурами и сухим климатом - менее 30 дождливых дней в году (Корея, Япония - 75 - 80 дождливых дней в году), что дает возможность развития и кооперации производства.

Кроме того, разветвленная сеть судоремонтных заводов на юге Украины с хорошей технической базой и специалистами, может стать базой для развития подрядных организаций, фабрикации блоков, сборки надстроек, их оборудование и комплектации, а также изготовление и поставки на заводы необходимого оборудования и отдельных деталей. Все это повышает объемы переработки металла и снижает стоимость судна, стоимость его ремонта и утилизации в целом [20].

Заказы по утилизации судов могут стать той сферой деятельности, которая позволит сохранить отрасль, особенно, если принять во внимание отсутствие конкуренции в этом бизнесе в Средиземно-Черноморском регионе. Данную идею нельзя считать новой. Еще в 90х годах прошлого века Украинский научно-исследовательский институт морского флота разрабатывал теоретические основы утилизации судов, СРЗ-ми выполнялись одиночные заказы по утилизации небольших судов и массивных металлоконструкций. Однако эффективность этих проектов оказалась недостаточной и продолжения таких работ признано практиками нецелесообразным. По нашему мнению, такой результат является следствием 
недостаточного научной проработки проблемы управления состоянием ОС от воздействия на нее производств различных типов и особенно предприятий утилизации.

За последние годы в мировой практике произошли глубокие качественные изменения в системе организации и управления природопользованием и охраны ОС.

Суть изменений - в подходах к решению экологических проблем, в постепенном отказе от преимущества традиционных методов управления и переходе к современным рыночным механизмам экологического регулирования.

При всей критике авторами, нельзя не отметить, что в Национальной транспортной стратегии Украины на период до 2030 года подчеркивается приоритетность необходимости охраны ОС во время развития морской инфраструктуры, в данном случае - УП.

Идея экоменеджмента зародилась в далеком прошлом. Еще в 1871 г. американский эколог Б. Коммонера попробовал сформулировать законы экологии, в которых четко прослеживается необходимость правления в отрасли сохранения ОС [21].

Появление в 1996 году международных стандартов СЭМ на предприятиях и в компаниях ISO серии 14000 называют одной из наиболее значительных международных природоохранных инициатив.

Решение о разработке ISO 14000 является результатом Уругвайского раунда переговоров по Всемирному торговому соглашению и встречи на высшем уровне в Рио-де-Жанейро в 1992 году по ОС и развитию [22, 23].

Общее назначение стандарта - содействовать охране ОС и предотвращать её загрязнение, учитывая социально-экономические потребности. Основой стандарта является методика Шухарта-Деминга: «Планируй-выполняй-проверяй-действуй», предусматривающая постоянное улучшение характеристик СЭМ, используя процессы и их взаимодействие (рис. 1). Авторы расширили круг Шухарта-Деминга, предложенный в работе [24].

Подготовка к внедрению СЭМ начинается с разработки стратегии УП и постановки экономико-экологических целей и формирования принципов экологической политики (Оценка экологических рисков, влияния различных производственных факторов на ОС, возможной упущенной выгоды от применения используемых устаревших технологий и морально устаревшего технологического оборудования). Экологическая политика формируется в рамках хозяйственной деятельности с учетом, состояния ОС, требований законодательных и других государственных нормативно-правовых актов, регламентирующих деятельность УП. При этом важно установить уровень ответственности УП за состояние ОС, экологическую безопасность. Все это поможет сделать детальный экономический анализ экологической деятельности УП и провести сравнение с деятельностью других УП.

Анализ должен охватывать широкий диапазон условий функционирования УП, включая возможные аварийные ситуации. Информация для осуществления анализа может быть получена в документации предприятия и методом прямых измерений параметров окружающей среды. Исходное состояние анализируется по следующим направлениям [25]:

- требования законодательных и других государственных нормативных актов;

- экологические аспекты деятельности УП, его продукция, услуги, оказывающие воздействие на $\mathrm{OC}$;

- оценка соблюдения требований внутренних и внешних стандартов, правил и норм;

- существующая практика и процедуре экологического менеджмента;

- политика и деловым процедурам по выполнению контрактов, поставок (в т.ч. с учетом экологических требований);

- реализация обратной связи по результатам анализа предыдущих случаев нарушения договоров (в т.ч. по экологическим причинам);

- возможности обеспечения преимуществ в конкурентоспособности за счет экологических факторов; 


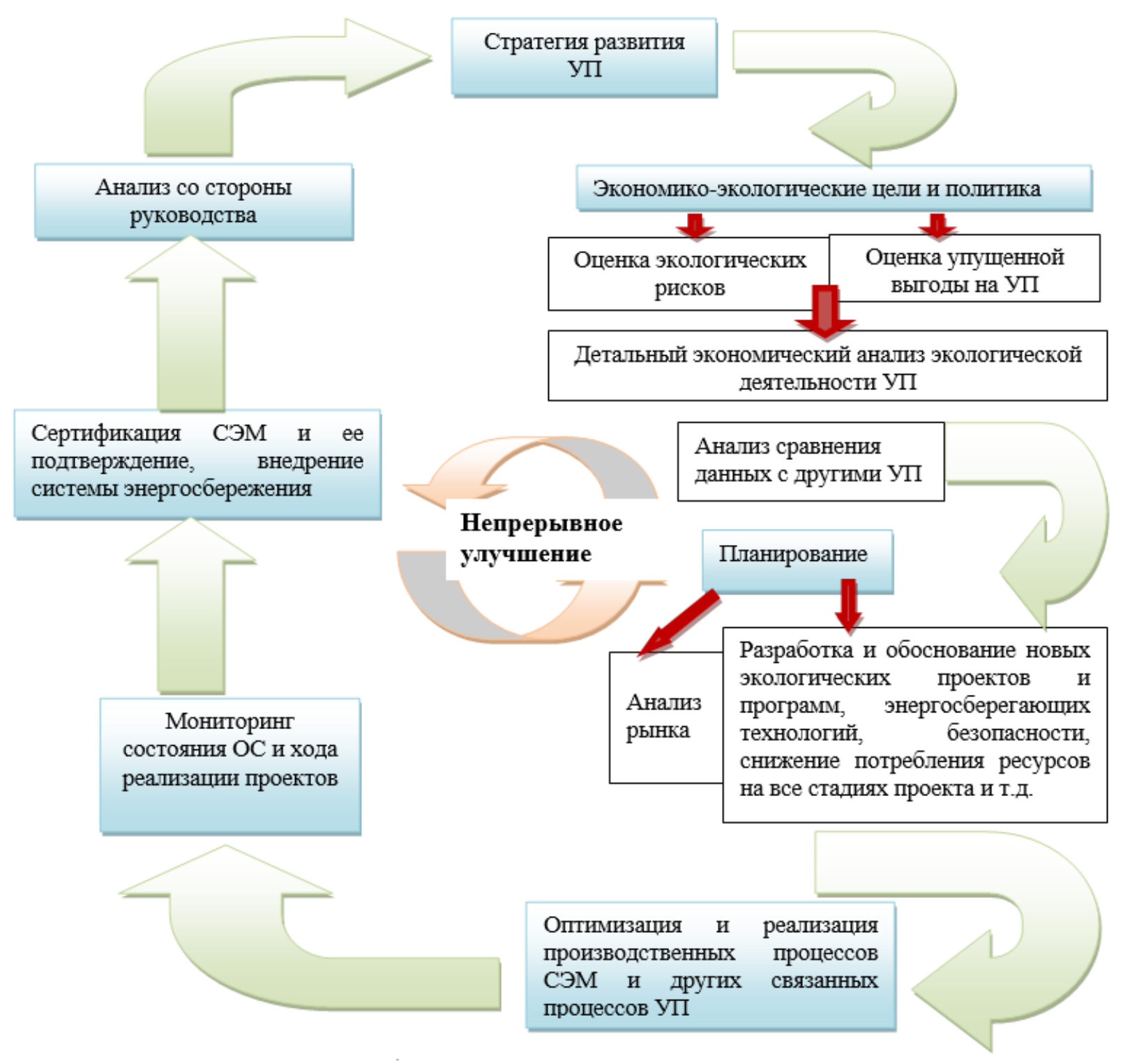

Рис.1. Модель системы экологического менеджмента УП

- оценка заинтересованными сторонами эффективности управления ОС УП (в т.ч. критические);

- функции и деятельности других организационно-технических систем, способствующим или препятствующим улучшению характеристик ОС.

По итогам анализа рынка выполняется планирование - оценивается возможность инвестирования в разработку новых экологических и энергосберегающих технологий с целью внедрения их на УП для дальнейшего снижения текущих затрат. Это позволяет оптимизировать процессы СЭМ и связанные с ним основные производственные процессы УП.

Экологический аспект включает характер, масштаб, интенсивность, вероятность, продолжительность воздействия на ОС. Хозяйственные аспекты включают возможность нормативно-правового регулирования; проблемы измерения характеристик воздействия; затраты на измерение уровня воздействий; влияние изменения характера деятельности или процесса на уровень воздействия.

УП должно идентифицировать и оценить все внешние и внутренние критерии. Внешние критерии - это нормативно-правовые и др. требования, непосредственно связанные с 
экологическими аспектами осуществляемой производственно-хозяйственной деятельности. Внутренние критерии разрабатываются и применяются при отсутствии внешних критериев, регламентирующих деятельность УП.

Например, УП может иметь свои внутренние критерии следующих видов деятельности [25]:

- система административного управления;

- обеспечение ответственности работников за охрану ОС;

- выбор поставщиков и субподрядчиков;

- управления сбытом продукции;

- организация природоохранной деятельности;

- отношения с контрольными и надзорными органами;

- подготовленность к аварийным экологическим ситуациям;

- осведомленности и обученности персонала в области охраны ОС;

- измерение характеристик экологичности и улучшения их;

- снижение производственного и экологического рисков;

- предотвращение загрязнений и образования отходов;

- ресурсосбережение, переход на возобновляемые ресурсы;

- проекты инвестиций (с включением экологических статей);

- модификация технологических процессов (перехода на безотходные и экономичные технологии);

- управление использованием комплектующих и сырьевых материалов, расходованием энергии.

Постоянно проводится мониторинг состояния ОС и хода реализации проектов. Он позволит обеспечивать получение информации для оценки соответствия экологических параметров деятельности предприятия требованиям нормативно-правовых актов по обеспечению экологической безопасности, проводить контроль за качеством объектов ОС, выявлять источники загрязнения, динамику выбросов (сбросов) вредных загрязняющих веществ, их прогнозирование. Информация, полученная в результате осуществления мониторинга, необходима на предприятии для планирования мероприятий по снижению загрязнения ОС и рациональному использованию природных ресурсов, определению приоритетных сфер деятельности, контроля и оценки эффективности осуществления природоохранных мер. На основе данных мониторинга осуществляется разработка комплексных, экологически ориентированных стратегических и оперативных мер по сокращению опасного воздействия на ОС и жизнедеятельность людей, контроль за соблюдением экологических нормативов и стандартов. Полученные результаты должны постоянно анализироваться, создавать предпосылки для формирования решений экологических проблем УП.

Далее УП внедряет энергосберегающие технологии и подает заявку на сертификацию по стандарту ДСТУ ISO 14001, затем ежегодно проходит технический надзор за данной системой либо ресертификацию (Ресертификащия (recertification) - это аудит, который проводит сертифицирующая организаџия у компании-держателя сертификата для того, чтобы убедиться, что можно «обновить сертификат» [26]). Таким образом, цикл замыкается, через какое-то время (от квартала до года) УП снова необходимо оценивать экологические риски и т.д. [27].

СЭМ способствует периодической оценке и анализу экологических характеристик УП, и как следствие - постоянному (непрерывному) улучшению.

Технический комитет ISO 207 разрабатывает стандарты серии ISO 14000, направленные на функционирование СЭМ организаций.

Обобщение стандартов серии ISO 14000, сделанное авторами на базе [25, 28, 29, 30], представлено в таблице 1 . 
Международные стандарты обеспечения СЭМ

\begin{tabular}{|c|c|c|}
\hline № & тандарты & Основные положения \\
\hline 1 & 2 & 3 \\
\hline 1 & $\begin{array}{c}\text { ISO } \\
\text { 14001: } 2015\end{array}$ & $\begin{array}{l}\text { Устанавливает требования для СЭМ } 1 \text { и, по мнению } \\
\text { экспертов ISO/TC 207/SC 1, отвечает последним тенденциям, таким } \\
\text { как увеличивающееся признание компаниями потребности учета } \\
\text { внешних и внутренних факторов и их воздействий, влияющих на OC, } \\
\text { включая изменчивость климата }\end{array}$ \\
\hline 2 & $\begin{array}{l}\text { ISO 14004: } \\
\quad 2016\end{array}$ & $\begin{array}{l}\text { «Системы экологического менеджмента - Руководящие указания } \\
\text { по применению». Стандарт носит рекомендательный характер и } \\
\text { применимы к любой организации, независимо от ее размера, типа, } \\
\text { месторасположения и уровня зрелости. } \\
\text { Содержит рекомендации по созданию, внедрению, } \\
\text { функционированию и совершенствованию эффективной СЭМ и ее } \\
\text { взаимодействию с другими системами менеджмента организации }\end{array}$ \\
\hline 3 & $\begin{array}{l}\text { ISO/CD } \\
14005\end{array}$ & $\begin{array}{l}\text { «Системы экологического менеджмента. Руководящие указания по } \\
\text { поэтапному внедрению системы экологического менеджмента с } \\
\text { использованием оценки экологической результативности», } \\
\text { разработан взамен его предыдущей версии } 2010 \text { года }\end{array}$ \\
\hline 4 & $\begin{array}{c}\text { ISO/CD } \\
14006\end{array}$ & $\begin{array}{l}\text { «Системы экологического менеджмента. Руководящие указания по } \\
\text { включению экологических норм при проектировании». Его первая } \\
\text { версия была опубликована в } 2011 \text { году }\end{array}$ \\
\hline 5 & ISO 14010 & $\begin{array}{l}\text { Руководство по экологическому аудиту - Общие принципы } \\
\text { экологического аудита }\end{array}$ \\
\hline 6 & ISO 1 & $\begin{array}{l}\text { Руководство по экологическому аудиту - Процедуры аудита - } \\
\text { Аудит систем экологического менеджмента }\end{array}$ \\
\hline 7 & ISO 14012 & $\begin{array}{l}\text { Руководство по экологическому аудиту - Критерии квалификации } \\
\text { экологических аудиторов }\end{array}$ \\
\hline 8 & ISO 14014 & $\begin{array}{l}\text { Руководство по определению "начального уровня" экологической } \\
\text { эффективности п предприятия. Должно использоваться } \quad \text { перед } \\
\text { созданием формальной системы экологического менеджмента } \\
\text { Инструменты экологического контроля и оценки } \\
\end{array}$ \\
\hline 9 & $\begin{array}{c}\text { ISO/CD } \\
14016\end{array}$ & $\begin{array}{l}\text { ический менеджмент - Руководство по обеспечению } \\
\text { кой отчетности» }\end{array}$ \\
\hline 10 & $\begin{array}{c}\text { ISO } 14020 \\
\text { (Серия } \\
\text { документов) } \\
\end{array}$ & ологической маркировки продукции \\
\hline 11 & ISO 14031 & $\begin{array}{c}\text { Руководство по оценке экологических показателей деятельности } \\
\text { организации. Стандарты, ориентированные на продукцию }\end{array}$ \\
\hline 12 & $\begin{array}{c}\text { ISO } 14040 \\
\text { (Серия } \\
\text { документов) } \\
\end{array}$ & $\begin{array}{l}\text { Методология "оценки жизненного цикла" - оценки экологического } \\
\text { воздействия, связанного с продукцией, на всех стадиях ее жизненного } \\
\text { цикла }\end{array}$ \\
\hline 13 & $\begin{array}{l}\text { ISO 14046: } \\
2014\end{array}$ & $\begin{array}{l}\text { Содержит принципы, требования и руководящие указания для } \\
\text { подготовки экологической отчетности по оценке воздействий, } \\
\text { которые влияют на качество воды }\end{array}$ \\
\hline
\end{tabular}


Продолжение табл.1

\begin{tabular}{|c|c|c|}
\hline 1 & 2 & 3 \\
\hline 14 & ISO 14050 & $\begin{array}{l}\text { Экологический менеджмент - Словарь. Стандарт определяет } \\
\text { основные понятия, связанные с природоохранной деятельностью } \\
\text { организаций, опубликованные в серии международных стандартов } \\
\text { ISO } 14000\end{array}$ \\
\hline 15 & $\begin{array}{l}\text { ISO/FDIS } \\
14055-1\end{array}$ & $\begin{array}{l}\text { «Environmental management - Guidelines for establishing good } \\
\text { practices for combatting land degradation and desertification - Part 1: } \\
\text { Good practices framework» («Экологический менеджмент - } \\
\text { Руководящие указания по созданию передовой практики борьбы с } \\
\text { деградацией земель и опустыниванием - Часть 1: Схемы передовой } \\
\text { практики»). }\end{array}$ \\
\hline 16 & ISO & $\begin{array}{l}\text { Руководство по учету экологических аспектов в стандартах на } \\
\text { продукцию }\end{array}$ \\
\hline 17 & ISO & $\begin{array}{c}\text { Экологический } \quad \text { менеджмент. } \text { Интегрирование } \\
\text { аспектов в проектирование и разработку продукции }\end{array}$ \\
\hline 18 & ISO 14063 & $\begin{array}{l}\text { Экологический менеджмент. Обмен экологической информацией. } \\
\text { Рекомендации и примеры }\end{array}$ \\
\hline 19 & ISO 1 & $\begin{array}{l}\text { Измерение, количественное измерение и уменьшение выбросов } \\
\text { парниковых газов }\end{array}$ \\
\hline 20 & $\begin{array}{l}\text { ISO/TR 073: } \\
2017\end{array}$ & $\begin{array}{l}\text { «Экологический менеджмент - Водный след - Иллюстративные } \\
\text { примеры применения ISO 14046» }\end{array}$ \\
\hline
\end{tabular}

Ключевым понятием серии ISO 14000 является понятие системы экологического менеджмента в организации (предприятии или компании). Поэтому центральным документом стандарта считается ISO 14001 - "Спецификации и руководство по использованию систем экологического менеджмента". В отличие от остальных документов, все его требования являются "аудируемыми" - предполагается, что соответствие или несоответствие им конкретной организации может быть установлено с высокой степенью определенности. Именно соответствие стандарту ISO 14001 и является предметом формальной сертификации. Все остальные документы рассматриваются как вспомогательные [29].

Стандарт ISO 14001 в Украине введен в действие с 15.05. 2006 г., как ДСТУ ISO 14001:2006, а 21.12.2015 был заменен на ДСТУ ISO 14001:2015, который действует с 01.07.2016. ДСТУ ISO 14001:2015 увеличивает обязательства по разработке экологической политики, формирует новый подход к защите ОС, основанный на предупреждающих действиях, а также усиливает роль высшего руководства.

Данный стандарт могут применять не только УП, но и все предприятия морской отрасли, которые ставят перед собой цель разработать и выполнять экологическую политику и задачи, учитывая правовые и другие требования.

Украина имеет уникальные возможности применения экологически чистых и безопасных решений в сегменте утилизации судов и создании УП на примере таких компаний как Van Oord, Hapag, Lloyd, Samskip, Wallenius Wilhelmsen, Jan De Nul, Boskalis (nо даннылм Ship breaking Platform), которые уже утилизирует суда с условиями, одобренными Евросоюзом.

\section{Выводы}

1. Без внедрения эффективной СЭМ, как составной части общей системы управления, эффективная работа УП невозможна. При этом, с учетом особенностей технологических процессов утилизации и мнения многих экспертов [31], оптимальной системой управления таким производством является проектно-ориентированное управление. 
2. СЭМ поможет УП снизить производственные расходы, рационально использовать ресурсы и уменьшить издержки воздействия на ОС.

3. Вопросы учета экологических факторов при разработке и проектировании УП, при его функционировании, а так же при поисках новых подходов управления должны быть первостепенными.

4. Совершенствование и развитие природоохранного законодательства, ужесточение экологических требований, заинтересованность государства, инвесторов, мотивация руководства и персонала УП, индивидуальная и коллективная ответственность каждого факторы влияния на ЭМ утилизационного предприятия.

\section{ЛИТЕРАТУРА}

1. Резолюция А.962(23). Руководство ИМО по утилизации судов (Приложение). 2003. $283 \mathrm{c.}$.

2. Platform publishes list of ships dismantle...shipbreakingplatform.org (дата обращения 07.02.2020).

3. Современные методические принципы формирования системы экологического менеджмента на предприятиях Украины / Межрегиональная академия управления персаналом. Северодонецкий институт. http://referatwork.ru/refs/source/ref-120665.html. URL: masters.donntu.org > grishko > library > tez9 современные методические принципы формирования (дата обращения 25.01.2020)

4. Пизинцали Л.В., Александровская Н.И., Кошарская Л.В. Предпосылки развития системы утилизации лома в Украине на примере железнодорожного и морского транспорта // Сборник научных трудов ДонИЖТ. 2014. №37. С. 157 - 162.

5. Пизинцали Л.В. Украина - проблемы утилизации судов // East European Scientific Journal. 2016. № 8. С. $100-104$.

6. Большаков О.П. Перспективный анализ деятельности современного утилизационного предприятия: дис. канд. экон. наук: 08.00.12 / Саратов. 2013. 156 с. URL: http://www.dissercat.com/content/perspektivnyi-analiz-deyatelnosti-sovremennogoutilizatsionnogo-predpriyatiya (дата обращения: 16.04.2018).

7. Каховка С.В., Хорева С.А. Основные виды металлоотходов и источники их образования // Промышленная экология: сборник трудов Международной научнотехнической конференции, 27-28 октября 2015 г. Минск: БНТУ. 2015. С. 327 - 332. (В. \& Хорева, 2015).

8. Love L.B., Hendrickson C.T., Conway-Schempf N.M. Municipal solid waste recycling issues // Journal of Environmental Engineering. 1999. V. 125, № 10. P. 944 - 949. doi: 10.1061/(ASCE)0733-9372(1999)125:10(944).

9. Драницын С.Н. Теоретические основы технической эксплуатации морского флота // Тр. ЦНИИМФ. 1979. Вып. 231. С. $14-81$.

10. Петрова Н.Е. Совершенствование оценки технического состояния судна в целях повышения безопасности мореплавания//Диссертация на соискание ученой степени канд. техн. наук. Мурманск. 2006. 185 с.

11. Модели оценки судов, активов морских предприятий и ресурсов океана: учеб. пособие // Морского государственного университета им адм. Г.Е. Невельского. - Владивосток. 2010. $357 \mathrm{c}$.

12. Адонина О.В., Каменский В.В., Лабутин В.Н., Маттис А.Р., Репин А.А., Дружинин М.M. Совершенствование открытой геотехнологии в соответствии со стандартом ИСО 14000 / Горный информационно-аналитический бюллетень (научно-технический журнал). М.: изд-во "Горная книга". Семинар №24. 2009. С. 372 - 376.

13. Семенова С.А. Эффективная система менеджмента качества как средство повышения конкурентоспособности отечественных предприятий / Российское предпринимательство. М.: изд-во «Креативная экономика». №2(2). 2009. С. 80 - 85.

14. Славинский Д.А., Хорошавин А.В., Смирнова М.В. Анализ новых международных требований к системам экологического менеджмента в контексте российских условий / 
Научный журнал НИУ ИТМО. СПб.: НИУ ИТМО. Серия «Экономика и экологический менеджмент». 2015. №4. С.336 - 340 .

15. Орлова А.Ф., Гавловская Г.В. Организационно-методологического обеспечения экологического менеджмента как фактора устойчивого развития / Проблемы экономики и юридической практики. 2013. №3. С. 126-129.

16. Кузнецова Ю.Ю., Филин И.В. Экологический менеджмент / Научный вестник МГТУ ГА. 2011. №166. С. $114-119$.

17. Фролова И.И., Архипова Т.В. Совершенствование экологического менеджмента на предприятии / Инновационная экономика: перспективы развития и совершенствования. Изд-во Закрытое акционерное общество «Университетская книга», №1(19), 2017. С. 382 $-387$.

18. Михайличенко К. Транспортна стратегія у національних інтересах України // Зовнішня торгівля: економіка, фінанси, право. 2017. № 2 С. 82 - 94.

19. Мультипликатор судостроения: Как повлияет развитие ... URL: cfts.org.ua > articles > multiplikator_sudostr... (дата обращения 24.01.2020).

20. Пизинцали Л.В. Проектирование утилизационного предприятия на базе судоремонтного завода / Л.В. Пизинцали, Л.В. Кошарская// Матеріали ХІ Міжнародної науково-практичної конференції «Управління проектами: стан та перспективи». Миколаїв: НУК, 2015. - С. 116 - 117.

21. Современные методические принципы ... URL: masters.donntu.org > grishko > library > tez9 (дата обращения 25.01.2020). Экологический менеджмент предприятия ecological ... URL: irbis-nbuv.gov.ua > irbis_nbuv > cgiirbis_64 (дата обращения 25.01.2020).

22. Опыт внедрения систем экологического менеджмента на ... URL: eco.com.ua > content > opyt-vnedreniya-sist... (дата обращения 24.01.2020).

23. Пизинцали Л.В., Шахов А.В. Экологический менеджмент предприятий по утилизации морских судов // Збірник наукових праць Інституту геохімії навколишнього середовища. 2016. Вип. 26. С. $50-59$.

24. Экологический менеджмент предприятия. URL: infomanagement.ru > lekciya , Ekologicheskii_... (дата обращения 24.01.2020).

25. Единый Стандарт.URL:1cert.ru: https://1cert.ru/stati/resertifikatsiya-po-standartu-iso-9001 | 2017 (дата обращения 25.01.2020).

26. Злепко С.М., Войнаренко М.П., Зинченко С.Г. (Україна, Вінниця). Опыт внедрения систем экологического менеджмента на предприятиях машиностроительной отрасли Украины / Збірник матеріалів II-го Всеукраїнського з'їзду екологів з міжнародною участю / Промислова екологія. 2009. С. 1 - 4. URL: http://eco.com.ua/sites/eco.com.ua/files/lib1/konf/2vze/zb_m/0164_zb_m_2VZE.pdf (дата обращения 28.01.2020).

27. Серия стандартов ISO 14000 - интерсерт-Украина URL: intercert.com.ua > articles > 67iso-14000 (дата обращения 04. 02. 2020).

28. ISO 14000 - международные стандарты в области систем ... URL: www.derevo.info > content > detail (дата обращения 04. 02. 2020).

29. Сертификация ISO 14001 - Сертификация ISO 9001, ISO URL:ukrenergosert.com.ua > sertifikacziya-iso-14...(дата обращения 04.02.2020).

30. Волков, В.П. Особенности формирования жизненного цикла на основе CALSтехнологии / В.П. Волков, И.В. Грицук, В.Н. Павленко, Н.В. Володарец // Вестник Харьковского национального автомобильно-дорожного университета. - Вып. 75. 2016. - C. $151-157$.

\section{REFERENCES}

1. Rezolyucziya A.962(23). Rukovodstvo IMO po utilizaczii sudov (Prilozhenie). [Resolution A.962 (23). IMO Guidelines for Ship Recycling] 2003. - 283 s.

2. Platform publishes list of ships dismantle... shipbreakingplatform.org (Accessed 07.02.2020). 
3. Sovremenny`e metodicheskie princzipy` formirovaniya sistemy` e`kologicheskogo menedzhmenta na predpriyatiyakh Ukrainy'[ Modern methodological principles for the formation of an environmental management system at Ukrainian enterprises] / Mezhregional naya akademiya upravleniya persanalom. Severodoneczkij institut. http://referatwork.ru/refs/source/ref-120665.html. URL: masters.donntu.org > grishko > library $>$ tez9 sovremenny`e metodicheskie princzipy` formirovaniya (Accessed 25.01.2020)

4. Pizinczali L.V., Aleksandrovskaya N.I., Kosharskaya L.V. Predposy`lki razvitiya sistemy` utilizaczii loma $\mathrm{v}$ Ukraine na primere zheleznodorozhnogo i morskogo transporta [Prerequisites for the development of a scrap recycling system in Ukraine by the example of rail and sea transport] // Sbornik nauchny`kh trudov DonIZhT. 2014. \#37. S. 157 - 162.

5. Pizinczali L.V. Ukraina - problemy` utilizaczii sudov [Ukraine - ship recycling problems] // East European Scientific Journal. 2016. \# 8. S. 100 - 104.

6. Bol`shakov O.P. Perspektivny`j analiz deyatel`nosti sovremennogo utilizaczionnogo predpriyatiya [Prospective analysis of the activities of a modern recycling enterprise]: dis. kand. e'kon. nauk: 08.00.12 / Saratov. 2013. 156 s. URL: http://www.dissercat.com/content/perspektivnyi-analiz-deyatelnosti-sovremennogoutilizatsionnogo-predpriyatiya (Accessed 16.04.2018).

7. Kakhovka, S.V., Khoreva S.A. Osnovny`e vidy` metallootkhodov i istochniki ikh obrazovaniya [The main types of metal waste and sources of their formation] // Promy`shlennaya e`kologiya: cbornik trudov Mezhdunarodnoj nauchno-tekhnicheskoj konferenczii, 27-28 oktyabrya 2015 g. Minsk: BNTU. 2015. S. 327 - 332. (V. \& Khoreva, 2015).

8. Love L.B., Hendrickson C.T., Conway-Schempf N.M. Municipal solid waste recycling issues // Journal of Environmental Engineering. 1999. V. 125, \# 10. R. 944 - 949. doi: 10.1061/(ASCE)0733-9372(1999)125:10(944).

9. Draniczy`n S.N. Teoreticheskie osnovy` tekhnicheskoj e`kspluataczii morskogo flota [Theoretical foundations of the technical operation of the navy] // Tr. CzNIIMF. 1979. Vy`p. 231. S. $14-81$.

10. Petrova N.E. Sovershenstvovanie oczenki tekhnicheskogo sostoyaniya sudna v czelyakh povy`sheniya bezopasnosti moreplavaniya [Improving the assessment of the technical condition of the vessel in order to improve the safety of navigation] //Dissertacziya na soiskanie uchenoj stepeni kand. tekhn. nauk. Murmansk. 2006. 185 s.

11. Modeli oczenki sudov, aktivov morskikh predpriyatij i resursov okeana [Valuation models for ships, assets of marine enterprises and ocean resources]: ucheb. posobie // Morskogo gosudarstvennogo universiteta im adm. G.E. Nevel`skogo. - Vladivostok. 2010. $357 \mathrm{~s}$.

12. Adonina O.V., Kamenskij V.V., Labutin V.N., Mattis A.R., Repin A.A., Druzhinin M.M. Sovershenstvovanie otkry`toj geotekhnologii $\mathrm{v}$ sootvetstvii so standartom ISO 14000 [Improving open geotechnology in accordance with ISO 14000] / Gorny j informaczionnoanaliticheskij byulleten` (nauchno-tekhnicheskij zhurnal). M.: izd-vo "Gornaya kniga". Seminar \#24. 2009. S. 372 - 376.

13. Semenova S.A. E`ffektivnaya sistema menedzhmenta kachestva kak sredstvo povy`sheniya konkurentosposobnosti otechestvenny'kh predpriyatij [An effective quality management system as a means of increasing the competitiveness of domestic enterprises] / Rossijskoe predprinimatel`stvo. M.: izd-vo «Kreativnaya e`konomika». \#2(2). 2009. S. 80 - 85.

14. Slavinskij D.A., Khoroshavin A.V., Smirnova M.V. Analiz novy`kh mezhdunarodny`kh trebovanij $\mathrm{k}$ sistemam e`kologicheskogo menedzhmenta $\mathrm{v}$ kontekste rossijskikh uslovij [Analysis of new international requirements for environmental management systems in the context of Russian conditions] / Nauchny’j zhurnal NIU ITMO. SPb.: NIU ITMO. Seriya «E'konomika i e'kologicheskij menedzhment». 2015. \#4. S.336 - 340.

15. Orlova A.F., Gavlovskaya G.V. Organizaczionno-metodologicheskogo obespecheniya e`kologicheskogo menedzhmenta kak faktora ustojchivogo razvitiya [Organizational and methodological support of environmental management as a factor in sustainable development] / Problemy` e’konomiki i yuridicheskoj praktiki. 2013. \#3. S. 126-129. 
16. Kuzneczova Yu.Yu., Filin I.V. E`kologicheskij menedzhment [Environmental management] / Nauchny`j vestnik MGTU GA. 2011. \#166. S. 114 - 119.

17. Frolova I.I., Arkhipova T.V. Sovershenstvovanie e`kologicheskogo menedzhmenta na predpriyatii [Improving environmental management in the company] / Innovaczionnaya e`konomika: perspektivy` razvitiya i sovershenstvovaniya. Izd-vo Zakry`toe akczionernoe obshhestvo «Universitetskaya kniga», \#1(19), 2017. S. 382 - 387.

18. Mikhajlichenko K. Transportna strategi ya u naczi`onal`nikh i`nteresakh Ukrayini [Transport strategy at the national interests of Ukraine] // Zovni'shnya torgi vlya: ekonomi ka, fi nansi, pravo. 2017. \# 2 S. 82 - 94.

19. Mul tiplikator sudostroeniya: Kak povliyaet razvitie ... [Shipbuilding multiplier: How development will affect .... URL: cfts.org.ua > articles > multiplikator_sudostr... (Accessed 24.01.2020).

20. Pizinczali L.V. Proektirovanie utilizaczionnogo predpriyatiya na baze sudoremontnogo zavoda [Design of a recycling facility based on a shipyard] / L.V. Pizinczali, L.V. Kosharskaya// Materi ali KhI Mi`zhnarodnoyi naukovo-praktichnoyi konferenczi yi «Upravli`nnya proektami: stan ta perspektivi». - Mikolayiv: NUK, 2015. - S. $116-117$.

21. Sovremenny`e metodicheskie princzipy`... [Modern methodological principles...] URL: masters.donntu.org > grishko > library > tez9 (data obrashheniya 25.01.2020). E'kologicheskij menedzhment predpriyatiya ecological ... URL: irbis-nbuv.gov.ua > irbis_nbuv > cgiirbis_64 (Accessed 25.01.2020).

22. Opy`t vnedreniya sistem e`kologicheskogo menedzhmenta na ... [Experience in implementing environmental management systems in ...] URL: eco.com.ua > content > opyt-vnedreniyasist... (data obrashheniya 24.01.2020).

23. Pizinczali L.V., Shakhov A.V. E`kologicheskij menedzhment predpriyatij po utilizaczii morskikh sudov [Экологический менеджмент предприятий по утилизации морских судов] // Zbi`rnik naukovikh pracz` I’nstitutu geokhi`mi`yi navkolishn`ogo seredovishha. 2016. Vip. 26. S. $50-59$.

24. E'kologicheskij menedzhment predpriyatiya. [Ecological Management of company] URL: infomanagement.ru > lekciya > Ekologicheskii_... (Accessed 24.01.2020).

25. Ediny j Standart. [One Standard] URL:1cert.ru: https://1cert.ru/stati/resertifikatsiya-postandartu-iso-9001 | 2017 (Accessed 25.01.2020).

26. Zlepko S.M., Vojnarenko M.P., Zinchenko S.G. (Ukrayina, Vi`nniczya). Opy`t vnedreniya sistem e`kologicheskogo menedzhmenta na predpriyatiyakh mashinostroitel’noj otrasli Ukrainy [Experience in implementing environmental management systems at enterprises in the engineering industry of Ukraine] / Zbi rnik materi ali`v II'-go Vseukrayins`kogo z'yizdu ekologi`v z mi zhnarodnoyu uchastyu / Promislova ekologi ya. 2009. S. 1 - 4. URL: http://eco.com.ua/sites/eco.com.ua/files/lib1/konf/2vze/zb_m/0164_zb_m_2VZE.pdf (Accessed 28.01.2020).

27. Seriya standartov ISO 14000 - intersert-Ukraina [A series of standards ISO 14000 - IntersertUkraine] URL: intercert.com.ua > articles > 67-iso-14000 (Accessed 04. 02. 2020).

28. ISO 14000 - mezhdunarodny`e standarty` v oblasti sistem ... [ISO 14000 - International System Standards ...] URL: www.derevo.info > content > detail (Accessed 04. 02. 2020).

29. Sertifikacziya ISO 14001 - Sertifikacziya ISO 9001, ISO [ISO 14001 Certification - ISO 9001, ISO Certification] URL: ukrenergosert.com.ua > sertifikacziya-iso-14... (Accessed 04.02.2020).

30. Volkov, V.P. Osobennosti formirovaniya zhiznennogo czikla na osnove CALS-tekhnologii [Features of the formation of the life cycle based on CALS technology] / V.P. Volkov, I.V. Griczuk, V.N. Pavlenko, N.V. Volodarecz // Vestnik Khar`kovskogo naczional`nogo avtomobil`no-dorozhnogo universiteta. - Vy`p. 75. - 2016. - S. $151-157$.

Пизинцали Л.В., Александровская Н.И., Россомаха Е.И., Никифоров Ю.А., Шахов В.И., Рабочая T.В.

ПРИНЦИПИ ФОРМУВАННЯ СИСТЕМИ ЕКОЛОГІЧНОГО МЕНЕДЖМЕНТУ ПІДПРИЕМСТВА 3 УТИЛІЗАЦЇ̈ МОРСЬКИХ СУДЕН В УКРАЇНІ 
Утилізація після закінчення терміну експлуатації суден $i$ кораблів різних типів $i$ призначення - актуальна $i$, одночасно, дуже складна $i$ серйозна проблема не тільки в технологічному, економічному та правовому плані, але, $i$ с серйозною екологічною проблемою.

Автори підкреслюють, щуо в прийнятій стратегії для розв'язання системних проблем не передбачені нові шляхи і ефективні методи відновлення і розвитку судноремонтних заводів Украӥни, і взагалі не згадується про проблеми великої кількості покинутих $і$ затоплених суден, пристаней, доків, причалів в затоках, в гирлах річок і навіть в портах.

При ефективної системи державної підтримки суднобудування дасть поштовх для інших галузей (машинобудування, металургія і ін.).

В умовах функиіонування системи екологічного управління виробнича діяльність на підприсмстві з утилізації морських суден, на думку авторів, може бути представлена $у$ вигляді різних видів екологічної діяльності (розробка, обгрунтування, аналіз, оцінки і т.д.), взаємопов'язаних між собою).

На думку авторів, один із шляхів реанімування суднобудівних і судноремонтних заводів, $\epsilon$ перепрофілювання їх повністю або частково в утилізачійні підприємства. Вкладення будуть відносно мінімальні, так як, буде збережена технічна база, живий $і$ прачює науководослідний потенціал, здатний забезпечити заводи сучасними проектами і розробками, а також, не можна не відзначити вигідне географічне положення, і прекрасні кліматичні умови.

У статті показано значення, роль $і$ вплив системи екологічного менеджменту на створення, і управління утилізаційного підприємства. Проведено узагальнення стандартів ISO 14000.

Ключові слова: утилізаиійного підприємство, екологічний менеджмент, система екологічного менеджменту, навколишнє середовище, стандарти ISO 14000.

\section{Pizintsali L.V., Aleksandrovskaya N.I., Rossomakha E.I., Nikiforov Yu.A., Shakhov V.I., Rabochaya T.V. \\ PRINCIPLES OF FORMING THE SYSTEM OF ECOLOGICAL MANAGEMENT OF THE ENTERPRISE FOR DISPOSAL OF MARINE VESSELS IN UKRAINE}

Utilization of outdated ships and ships of various types and purposes is an urgent and, at the same time, very difficult and serious problem not only in technological, economic and legal terms, but also is a serious environmental problem.

The authors emphasize that the adopted strategy for unleashing systemic problems does not provide new ways and effective methods for the restoration and development of shipyards in Ukraine, and generally does not mention the problems of a large number of abandoned and flooded ships, marinas, docks, moorings in inlets, in river mouths and even in ports.

With an effective system of state support, shipbuilding will give an impetus to other sectors (engineering, metallurgy, etc.).

In the conditions of the functioning of the environmental management system, production activities at the shipboard recycling enterprise, according to the authors, can be represented in the form of various types of environmental activities (development, justification, analysis, assessment, etc.), interconnected).

According to the authors, one of the ways to reanimate shipbuilding and ship repair yards is to reorient them in whole or in part in a unitary enterprise. Investments will be relatively minimal, as the technical base will be preserved, the research and development potential alive and working, capable of providing the plants with modern projects and developments, and also, it is necessary to note the advantageous geographical position, and excellent climatic conditions.

The article shows the significance, role and influence of the environmental management system on the creation and management of a recycling enterprise. The generalization of ISO 14000 standards is carried out.

Key words: utilization enterprise, environmental management, environmental management system, environment, ISO 14000 standards. 